\title{
OSOBINE LIČNOSTI I PONAŠANJE VOZAČA U SAOBRAĆAJU
}

\section{Sonja Vukobrat ${ }^{1}$ i Dušanka Mitrović}

Filozofski fakultet, Novi Sad

U radu je prikazano istraživanje strukture povezanosti osobina ličnosti $i$ ponašanja vozača u saobraćaju. Uzorak ispitanika činilo je 180 osoba oba pola sa položenim vozačkim ispitom, starosti izmedu 18 i 69 godina, a primenjena su dva instrumenta: Upitnik o ponašanju u saobraćaju (UPS) i Zakermanov i Kalmanov upitnik ličnosti (ZKPQ). Analizom glavnih komponenti prostor merenja upitnika UPS sveden je na četiri glavne komponente: Kršenje propisa, Impulsivnost u vožnji, Bezbedna vožnja $i$ Razdražljivost u vožnji.

Analiza strukture povezanosti izmedu dimenzija ličnosti i aspekata ponašanja pri vožnji ukazala je na dva obrasca povezanosti ova dva skupa. Prvi opisuje povezanost skorova na dimenzijama Agresivnost-hostilnost $i$ Impulsivnost sa razdražljivim i impulsivnim ponašanjem prilikom vožnje, $i$ ukazuje na to da agresivna uznemirenost tokom vožnje i oblici rizičnog ponašanja odražavaju stabilne osobine ličnosti vozača. Drugi obrazac povezanosti opisuje vezu stepena miroljubivosti i potrebe za aktivnošću sa odgovornošću i uživanjem u vožnji. Ovaj obrazac sugeriše $i$ da samouverenost kada su u pitanju vozačke veštine utiče na sklonost ka kršenju propisa, ali verovatno ne $i$ na visoko rizičnu vožnju. Rezultati generalno ukazuju na poseban značaj dimenzija Agresivnost-hostilnost i Impulsivnost $u$ ovom kontekstu, $i$ imaju potencijalnu primenu u oblasti prevencije saobraćajnih nezgoda. Nalazi su uglavnom u skladu sa rezultatima dosadašnjih studija u ovom području.

Ključne reči: osobine ličnosti, Alternativni petofaktorski model ličnosti, ponašanje vozača u saobraćaju

\footnotetext{
${ }^{1}$ somentality@gmail.com
} 


\section{Uvod}

Prema podacima Srpskog komiteta za bezbednost saobraćaja (2009), u poslednjih nekoliko godina u saobraćajnim nesrećama u Srbiji pogine prosečno oko 900 osoba godišnje. Na osnovu ovih i još nekih pokazatelja, Srbija se nalazi na samom dnu lestvice bezbednosti saobraćaja u Evropi. Za razliku od ostalih evropskih zemalja, $u$ kojima iz godine u godinu opada broj povređenih u saobraćajnim nesrećama, u Srbiji je u poslednjih nekoliko godina trend suprotan. Iako je u 2008. godini trend porasta broja povređenih zaustavljen, ovi podaci su zabrinjavajući i pokreću brojna pitanja. Svakako je jedno od najvažnijih pitanja vezano za uzroke nesreća i mogućnost da se ovakvi tragični događaji spreče.

Uloga osobina ličnosti u ponašanju vozača je problem koji je već privukao pažnju brojnih istraživača, naročito zbog toga što se ljudski faktor pokazuje kao najznačajniji uzrok saobraćajnih nesreća. Naime, podaci govore da ponašanje čoveka uzrokuje nezgode u preko $90 \%$ slučajeva. Ponašanje vozača u saobraćaju je vrlo složeno jer uključuje reakcije na veći broj istovremenih informacija u situacijama koje se stalno menjaju. Od kvaliteta i brzine reagovanja vozača zavisiće njegova bezbednost i bezbednost drugih učesnika u saobraćaju (Vukadinović, 1979). Pitanje koje se može postaviti je da li specifičnost situacija u koje osoba dolazi dok vozi (npr. konflikti sa drugim osobama u saobraćaju od kojih je vozač fizički odvojen i sl.) može isprovocirati ponašanja koja inače nisu karakteristična za osobu u brojnim drugim životnim situacijama, ili, kao što smatraju mnogi autori, „čovek vozi kako živi“ (Tillman \& Hobbs, 1949).

Rezultati nekih istraživanja podržavaju gledište da je ponašanje vozača samo donekle opravdano posmatrati kao deo opšteg stila življenja. Tako su Zakerman i Kalman (Zuckerman \& Kuhlman, 2000), u kontekstu istraživanja relacija između osobina ličnosti i sklonosti preuzimanju rizika, ispitivali i neke aspekte ponašanja pri vožnji. Rezultati su ukazali na povezanost generalne sklonosti ka preuzimanju rizika sa skalama Impulsivno traženje senzacija, Agresivnost i Socijabilnost, kao i na nepostojanje povezanosti sa skalama Neuroticizam i Aktivitet. Međutim, sklonost rizičnoj vožnji, kao i pojačana konzumacija alkohola, nisu pokazale značajne korelacije sa ostalim ispitivanim oblastima rizičnog ponašanja kao što su pušenje, droga, rizično seksualno ponašanje i kockanje. Dakle, na osnovu ovih rezultata moglo bi se zaključiti da ponašanje vozača ne mora u velikoj meri korespondirati sa ostalim njegovim ponašanjima, bar kada je reč o rizičnom ponašanju, pa tako ni sa osobinama ličnosti koje se mogu smatrati predisponirajućim za takva ponašanja. 
Međutim, neka istraživanja koja su se bavila ponašanjem vozača kao izdvojenim fenomenom sugerišu da povezanost između osobina ličnosti i ponašanja vozača postoji, i da priroda te povezanosti uglavnom podržava stav da se ljudi prilikom vožnje ponašaju na sličan način kao i u drugim situacijama. Tako su rezultati studije sprovedene na uzorku mladih iz Norveške (Oltedal \& Rundmo, 2006) ukazali na značajnu korelaciju anksioznosti i traženja senzacija sa rizičnom vožnjom, a takođe i traženja senzacija i rizične vožnje sa nezgodama u saobraćaju. Međutim, osobine ličnosti i pol objasnile su relativno mali procenat varijanse rizične vožnje. Najveći deo varijanse rizične vožnje objasnile su opšta sklonost kršenju pravila i iritabilnost, a pol se pokazao takođe kao dobar prediktor - muškarci su pokazali veću sklonost ka rizičnoj vožnji. Rezultati istraživanja Dejlena i Vajta (Dahlen \& White, 2006) podržavaju korišćenje multiplih prediktora pri proučavanju nebezbedne vožnje i pokazuju da se različiti aspekti ponašanja vozača mogu objasniti različitim kombinacijama prediktora. Kao dobri prediktori pokazali su se bes prilikom vožnje, traženje senzacija, emocionalna stabilnost, prijatnost i otvorenost ka iskustvu. Otvorenost je pokazala povezanost sa rizičnom vožnjom, a prijatnost sa gubljenjem kontrole nad vozilom, dok je emocionalna stabilnost predviđala agresivnu vožnju. Traženje senzacija se pokazalo kao dobar prediktor niza karakteristika, kao što su rizična neagresivna vožnja, agresivna vožnja, gubljenje koncentracije pri vožnji, manje nezgode i ozbiljnije nesreće u saobraćaju. Među studijama čiji rezultati ukazuju na prediktivni značaj osobine traženje senzacija za ponašanje vozača je i istraživanje Iversena i Rundma (Iversen \& Rundmo, 2002). Dobijeni rezultati su pokazali da osobe koje postižu visoke skorove na traženju senzacija i besu pri vožnji izveštavaju o čestoj rizičnoj vožnji i imaju češća iskustva sudara koji su prouzrokovali povrede i materijalnu štetu.

U studiji kroskulturalnog karaktera (Lajunen, 2001) korišćeni su podaci o prosečnim skorovima 34 zemlje na skalama upitnika EPQ, koje su objedinili Lin i Hempson (Lynn \& Hampson, 1995, prema Lajunen, 2001), kao i podaci o broju saobraćajnih nesreća sa fatalnim ishodom u tim zemljama. Pokazano je da se u zemljama koje postižu visoke prosečne skorove na ekstraverziji događa veći broj saobraćajnih nesreća $s$ fatalnim ishodom. Takođe, veći broj ovakvih nesreća se beleži u zemljama kod kojih je prosečan skor na neuroticizmu visok ili nizak, u odnosu na one zemlje koje postižu umerene skorove. Skorovi na psihoticizmu nisu pokazali vezu sa saobraćajnim nezgodama.

Ozkan i Lajunen (Özkan \& Lajunen, 2005) su razvili instrument za merenje lokusa kontrole vozača. Pokazali su da je sklonost da se uzroci doživljenih ili potencijalnih saobraćajnih nezgoda pripisuju sebi prediktor ukupnog broja 
nezgoda, prekršaja i grešaka, dok je sklonost da se uzroci pripisuju drugim vozačima bila u negativnoj korelaciji sa greškama.

Istraživanja koja su se bavila fenomenom besa pri vožnji pokazala su da su ljutiti vozači skloniji rizičnom ponašanju i manjim nezgodama u saobraćaju od vozača sa niskim stepenom besa. Kada su u pitanju karakteristike ličnosti, vozače sa visokim stepenom besa pri vožnji od vozača sa niskim stepenom besa razlikuju viši skorovi na agresivnosti, anksioznosti, potiskivanju besa i nekontrolisanom ispoljavanju besa (Deffenbacher, Huff, Lynch, Oetting \& Salvatore, 2000). Pokazalo se i da se grupa ljutitih vozača koja priznaje da ima probleme sa besom prilikom vožnje i koja je zainteresovana za savetovanje, razlikuje po izraženosti nekih karakteristika ličnosti od grupe ljutitih vozača koji ne smatraju da imaju problema sa besom i nisu motivisani da zatraže stručnu pomoć. Iako se ove dve grupe ne razlikuju po stepenu besa pri vožnji, o kome izveštavaju, i po karakteristikama kao što su rizično ponašanje i impulsivnost, razlika se ogleda u nešto većem stepenu agresivnosti i besa kao crta ličnosti, kao i slabijoj kontroli besa kod vozača koji procenjuju da im je potrebno savetovanje. Obe grupe ljutitih vozača se razlikuju od grupe vozača sa niskim stepenom besa pri vožnji po tome što pokazuju veći stepen izraženosti različitih aspekata agresivnosti, impulsivnosti, i koriste manje adaptivne strategije prevladavanja (Deffenbacher, Filetti, Richards, Lynch \& Oetting, 2003). Milar (Millar, 2007) je pokazao da bes u interakciji sa osobinom označenom kao javna samosvesnost utiče na pojavu agresivne vožnje. Karakteristika označena kao javna samosvesnost predstavlja tendenciju da se usredsredi pažnja na sebe kao na socijalni objekt, pa osobe koje postižu više skorove pridaju veliki značaj utisku koji ostavljaju na druge i pridržavaju se društvenih normi. Rezultati su podržali hipotezu autora da se kod vozača koji pokazuju izražen bes agresivnije ponašanje pri vožnji pojavljuje ukoliko je njihova javna samosvesnost niska nego ukoliko je visoka.

Poseban problem kojim su se istraživači bavili je vožnja pod uticajem alkohola. U cilju osmišljavanja diferenciranog pristupa i tretmana vozača uhapšenih zbog vožnje pod uticajem alkohola, neka istraživanja su se bavila tipologijom ovih osoba (Donovan \& Marlatt, 1982; Nolan, Johnson \& Pincus, 1994). Rezultati su ukazali na mogućnost izdvajanja pet tipova ličnosti, od kojih su dva tipa pokazala crte koje posebno povećavaju rizik od udesa: prvi karakteriše visok stepen depresivnosti i ogorčenosti i nizak stepen asertivnosti, emocionalne prilagođenosti i percipirane kontrole; za drugi je karakterističan visok nivo agresivnosti u vezi s vožnjom, traženje senzacija, iritabilnost, kao i indirektna i verbalna hostilnost. 
Istraživanja koja su proučavala umor pri vožnji koristila su simulaciju vožnje. U jednoj studiji pokazano je da je neuroticizam dobar prediktor stepena distresa i umora usled vožnje (Matthews \& Desmond, 1998). Pokazalo se da su vozači koji postižu više skorove na ekstraverziji nešto skloniji da zapadnu u san i skrenu s puta tokom simulirane noćne vožnje, dok su osobe sa višim skorovima na dezinhibiciji bile sklonije da prelaze ivičnjak, ali naizgled nisu upadale u san (Verwey \& Zaidel, 2000). Lična procena učesnika u vezi sa sopstvenom sklonošću da se zadrema tokom vožnje pokazala se kao loš prediktor ovakvog ponašanja u situaciji simulirane vožnje. Rezultati studije simulirane vožnje u monotonim i nemonotonim uslovima pokazali su da je ukupan skor na traženju senzacija dobar prediktor umora u uslovima monotonog i repetitivnog okruženja, dok je njegova subdimenzija traženje iskustava povezana sa umorom i u monotonim uslovima i u uslovima u kojima vizuelni elementi prekidaju monotoniju (Thiffault \& Bergeron, 2003).

Budući da fenomen ponašanja vozača i njegove relacije sa osobinama ličnosti nisu privukli veliku pažnju domaćih autora, osnovni cilj ovog istraživanja je da se ispita da li te relacije postoje i kakva je njihova priroda. Sporedni cilj je ispitivanje strukture prostora merenja novokonstruisanog upitnika o ponašanju vozača u saobraćaju. Ponašanje vozača je shvaćeno kao skup određenih navika, sklonosti i emocionalnih reakcija prilikom vožnje, a uključuje i evaluaciju kvaliteta sopstvene vožnje. Kao referentni okvir za procenu osobina ličnosti korišćen je Zakermanov alternativni petofaktorski model ličnosti (Zuckerman, Joireman, Kraft \& Kuhlman, 1999), s obzirom na to da on obuhvata osobine koje su u dosadašnjim istraživanjima pokazale značajnu povezanost sa određenim aspektima ponašanja u saobraćaju. Može se pretpostaviti poseban značaj osobine impulsivno traženje senzacija, a zatim i agresivnosti i anksioznosti, u ovom kontekstu. Indirektno, rezultati bi trebalo da pomognu u identifikaciji osoba koje su sklonije nezgodama i na taj način usmere kreiranje diferenciranih programa prevencije saobraćajnih nezgoda.

\section{Metod}

\section{Instrumenti}

\section{Upitnik o ponašanju vozača u saobraćaju UPS}

Upitnik o ponašanju vozača u saobraćaju UPS (Vukobrat, 2008) sastoji se od 51 stavke s petostepenim Likertovim skalama. Stavke se odnose na različite aspekte ponašanja vozača u saobraćaju. Obuhvataju ponašanja kao što su poštovanje propisa, sklonost rizičnom ponašanju, razdražljivost i sl. Analizom 
glavnih komponenti na osnovu Scree kriterijuma izolovane su 4 glavne komponente upitnika koje su postavljene u Promax poziciju.

Prvu glavnu komponentu određuju ajtemi kao što su „Izazvao/la sam saobraćajni udes“, „Više puta sam kažnjavan/a za prekršaje koji ne podrazumevaju nepropisno parkiranje“, „Kažnjen/a sam više puta zbog nepropisnog parkiranja“, „Više puta sam kažnjen/a zbog prebrze vožnje“, „Često dovodim sebe u rizične situacije u saobraćaju“, „Krivično sam gonjen/a zbog prekršaja koji sam počinio/la“, „Vozim i ako popijem više nego što je dozvoljeno“. Faktor se odnosi na sklonost kršenju saobraćajnih propisa, a uključuje i indikatore rizične vožnje. Imenovan je kao Kršenje propisa.

Druga glavna komponenta definisana je negativnom projekcijom ajtema koji se odnose na staloženost i trezvenost pri vožnji („Smatram da vozim staloženo i odgovorno“, „Uglavnom poštujem saobraćajna pravila“), i pozitivnim korelacijama ajtema koji govore o nepromišljenom, impulsivnom i egocentričnom ponašanju vozača („Često mi se desi da prođem kroz crveno“, „Vozim oštro“, „Parkiram najbliže mestu na koje idem, pa iako "zagradim" nekog", „Jedem u kolima dok vozim“ „Vozim brže od većine ljudi“, „Razgovaram mobilnim telefonom dok vozim“). Glavna komponenta je imenovana kao Impulsivnost pri vožnji.

Treća Promax glavna komponenta određena je indikatorima usmerenosti na obezbeđivanje ugodnosti i bezbednosti vožnje, pozitivnog afekta koji prati vožnju, kao i pozitivne evaluacije sopstvenih vozačkih veština. Neki od njih su: „Verujem da je mojim saputnicima prijatno kada ih vozim“, „Sebe smatram spretnom osobom kada je u pitanju vožnja“, „Smatram da vozim bezbedno“, „Volim da vozim“, „Često proveravam ispravnost svog vozila“, „Poštujem prvenstvo prolaza na raskrsnicama“, „Nisam nervozan/a dok vozim“, „Volim velika i brza kola“. Predloženi naziv je Bezbedna vožnja.

Četvrtu glavnu komponentu oblikovali su različiti indikatori negativnih osećanja tokom vožnje, kao što su razdražljivost i hostilnost. Neki od njih su „Nerviraju me ljudi koji "kilave" u saobraćaju“, „Psujem dok vozim“, „Nerviraju me biciklisti koji voze van biciklističke staze“, „Nerviraju me penzioneri u saobraćaju“, „Kada vozim van grada, imam potrebu da preteknem vozilo ispred sebe, čak i ako se ono ne kreće sporo“, „Trubim kada neko na semaforu ne krene čim se upali zeleno svetlo“, „Nerviraju me žene u saobraćaju“. Ova glavna komponenta je imenovana kao Razdražljivost pri vožnji.

Faktori Kršenje propisa, Impulsivnost pri vožnji i Razdražljivost pri vožnji su u umerenim pozitivnim interkorelacijama, dok je faktor Bezbedna vožnja u zanemarljivoj korelaciji sa ostalima. 


\section{Zuckerman-Kuhlman Personality Questionnaire - ZKPQ}

Upitnik ličnosti Zakermana i Kalmana (Zuckerman-Kuhlman Personality Questionnaire - ZKPQ; Zuckerman, 2002) je instrument za procenu dimenzija ličnosti Alternativnog petofaktorskog modela. Sastoji se od 99 ajtema sa binarnim formatom odgovora. Obuhvata sledeće supskale:

1. Aktivitet (Act). Obuhvata dve supskale. Supskala Generalni aktivitet se odnosi na generalnu potrebu za aktivnošću, kao i na uznemirenost u situacijama u kojima ne postoji mogućnost da se ta potreba zadovolji. Druga grupa stavki se odnosi na sklonost ka teškim i izazovnim poslovima i nosi naziv Radni aktivitet.

2. Agresivnost - Hostilnost (Agg-Host). Odnosi se na verbalnu agresivnost, grubo, neobazrivo ponašanje, kao i zluradost, osvetoljubivost i nestrpljivost.

3. Impulsivno traženje senzacija (ImpSS). Obuhvata dve supskale: Impulsivnost i Traženje senzacija. Prva se odnosi na tendenciju ka impulsivnom reagovanju i odsustvu planiranja. Druga se odnosi na potrebu za uzbuđenjem i upuštanjem u nepredvidive situacije, kao i za stalnim promenama i novinama.

4. Neuroticizam - Anksioznost (N-Anx). Obuhvata emocionalnu uznemirenost, napetost, zabrinutost, strašljivost i osetljivost na kritiku.

5. Socijabilnost (Sy: sadrži dve supskale. Supskala Sklonost druženju i zabavama odnosi se na uživanje u zabavama i kontaktima sa velikim brojem ljudi. Supskala Tolerancija na izolaciju odnosi se na stepen tolerancije na socijalnu izolaciju, pri čemu socijabilnije osobe na njoj postižu niže skorove.

\section{Uzorak ispitanika}

U istraživanju je učestvovalo 180 ispitanika oba pola, različitog obrazovanja i starosti od 18 do 69 godina. Čine ga studenti, zaposleni i manji broj penzionera. Uzorak je heterogen po pitanju dužine vozačkog staža i učestalosti vožnje. Uslov za učešće u istraživanju bio je položen vozački ispit.

\section{Postupak}

Prikupljanje podataka je obavljeno u maju 2008. godine, na području Zrenjanina, Novog Sada i Subotice. Ispitanicima je dato uputstvo za odgovaranje i zagarantovana anonimnost odgovora. 


\section{Rezultati}

Relacije između dimenzija ponašanja u saobraćaju i dimenzija ličnosti

U kanoničkoj korelacionoj analizi levi skup varijabli predstavljaju faktorski skorovi na glavnim komponentama ekstrahovanim iz upitnika UPS, a desni skup faktorski skorovi na prvim glavnim komponentama supskala upitnika ZKPQ.

Tabela 1. Koeficijenti kanoničkih korelacija i njihova značajnost

\begin{tabular}{cccccc}
\hline & $\mathrm{Rc}$ & $\mathrm{Rc}^{2}$ & Lambda & $\mathrm{df}$ & $\mathrm{p}$ \\
\hline 1 & 0.596 & 0.355 & 0.499 & 32 & 0.000 \\
2 & 0.379 & 0.143 & 0.774 & 21 & 0.002 \\
3 & 0.295 & 0.087 & 0.904 & 12 & 0.134 \\
4 & 0.100 & 0.010 & 0.990 & 5 & 0.886 \\
\hline
\end{tabular}

Ekstrahovana su dva para statistički značajnih kanoničkih faktora (Tabela 1).

Tabela 2. Struktura kanoničkih faktora iz prostora skale UPS

\begin{tabular}{lcc}
\hline & Prvi kanonički faktor & $\begin{array}{c}\text { Drugi kanonički } \\
\text { faktor }\end{array}$ \\
\hline Kršenje propisa & 0.033 & $\mathbf{- 0 . 6 6 4}$ \\
Impulsivna vožnja & $\mathbf{- 0 . 4 3 6}$ & -0.121 \\
Bezbedna vožnja & -0.143 & $\mathbf{- 0 . 8 2 7}$ \\
Razdražljivost pri vožnji & $\mathbf{0 . 7 4 7}$ & $\mathbf{0 . 4 9 8}$ \\
\hline
\end{tabular}

Tabela 3. Struktura kanoničkih faktora iz prostora skale ZKPQ

\begin{tabular}{lcc}
\hline & Prvi kanonički faktor & Drugi kanonički faktor \\
\hline Traženje senzacija & -0.168 & -0.182 \\
Impulsivnost & $\mathbf{- 0 . 4 1 7}$ & $\mathbf{- 0 . 6 5 9}$ \\
Neuroticizam-anksioznost & 0.023 & 0.162 \\
Agresivnost-hostilnost & $\mathbf{- 0 . 6 2 7}$ & $\mathbf{0 . 7 0 1}$ \\
Generalni aktivitet & 0.138 & -0.120 \\
Radni aktivitet & -0.155 & $\mathbf{- 0 . 3 2 2}$ \\
Sklonost druženju i zabavama & -0.077 & -0.209 \\
Tolerancija na izolaciju & 0.023 & 0.007 \\
\hline
\end{tabular}


Kanonička korelacija između faktora prvog para je umerena. Kanonički faktor iz prostora skale UPS je određen varijablama Razdražljivost pri vožnji i Impulsivna vožnja (Tabela 2), a faktor iz prostora osobina ličnosti varijablama Agresivnost-hostilnost i Impulsivnost (Tabela 3). Ovaj obrazac povezanosti ukazuje na stil vožnje koji bi se mogao okarakterisati kao agresivno-impulsivni, te sugeriše da se osobe sa visokom agresivnošću i impulsivnošću ponašaju dok voze na sličan način kao i u drugim situacijama.

Drugi par kanoničkih faktora je u blagoj međusobnoj korelaciji. Dok kanonički faktor iz prostora skale UPS određuju, donekle kontradiktorno, faktori Bezbedna vožnja i Kršenje propisa na istom polu, a na drugom polu Razdražljivost pri vožnji, faktor iz prostora ZKPQ uključuje Impulsivnost i Radni aktivitet na jednom polu, a Agresivnost-hostilnost na drugom polu faktora. Ovaj obrazac povezanosti opisuje tendenciju impulsivnih, energičnih i aktivnih, ali neagresivnih osoba da vožnju doživljavaju kao prijatnu aktivnost i procenjuju da voze sigurno i bezbedno, iako izveštavaju i o tome da su sklone kršenju pravila. Čini se da ova kanonička relacija u izvesnoj meri opisuje osnovni afekat koji prati aktivnost vožnje.

\section{Diskusija}

Iako analiza strukture upitnika UPS nije bila osnovni cilj istraživanja, čini se da njeni rezultati ipak zaslužuju komentar. Upitnik UPS uključuje četiri aspekta ponašanja pri vožnji koja mogu biti relevantna za procenu stila vožnje $i$, naročito, rizičnih oblika ponašanja pri vožnji. Ti aspekti su imenovani kao $\mathrm{Kr}$ šenje propisa, Impulsivnost pri vožnji, Bezbedna vožnja i Razdražljivost pri vožnji.

Kršenje propisa, pored jasne tendencije da se ignorišu saobraćajna pravila, i istorije kažnjavanja usled toga, uključuje i sklonost da se ulazi u različite rizične i opasne situacije prilikom vožnje. Verovatno je da osobe koje postižu visok skor na ovom faktoru prosto ne mare za pravila, već su rukovođene isključivo svojim potrebama i ciljevima. Impulsivnost pri vožnji podrazumeva tendenciju da se neodložno zadovolje svoje potrebe i da se pri tom zanemaruju potrebe drugih ljudi i bezbednost vožnje. U pitanju je neplansko reagovanje, udovoljavanje trenutnim željama i osećanjima. Bezbedna vožnja podrazumeva odgovorno ponašanje vozača, koje uključuje poštovanje propisa čije bi kršenje direktno moglo ugroziti učesnike u saobraćaju, brigu o ispravnosti vozila, uverenje u vlastitu vozačku veštinu i pozitivan afektivni odnos prema vožnji. Razdražljivost pri vožnji podrazumeva negativan afekat pri vožnji i snažnu tenziju koja prati ovu aktivnost. Uključuje nestrpljenje, različite agresivne postupke i 
netrpeljivost prema različitim grupama učesnika u saobraćaju, uglavnom onim za koje važe stereotipi da usporavaju saobraćaj ili čine greške u vožnji. Umerena pozitivna korelacija među faktorima Razdražljivost pri vožnji, Kršenje propisa i Impulsivnost pri vožnji može poticati od toga što pretpostavljanje sopstvenih potreba pravilima i bezbednosti u nekoj meri zasićuje sva tri faktora. Ova tri faktora obuhvataju aspekte vozačkog ponašanja koji predstavljaju nebezbednu vožnju. Faktor Razdražljivost pri vožnji obuhvata aspekte ponašanja vozača slične onima koji su obuhvaćeni nekim upitnicima namenjenim proceni stepena besa prilikom vožnje, kao što je Driving Anger Scale (DAS; Deffenbacher, Oetting \& Lynch, 1994) i Driving Anger Expression Inventory (DAX; Deffenbacher, Lynch, Oetting, \& Swaim, 2002). Ostali faktori u izvesnoj meri korespondiraju s nekim supskalama u okviru upitnika namenjenih proceni ponašanja vozača, kao što je Driver Behavior Questionnaire (DBQ), razvijen na osnovu teorijske taksonomije aberantnih ponašanja vozača (Reason, 1990, prema Özkan, Lajunen \& Summala, 2006). Pomenuti upitnik obuhvata dve kategorije takvih ponašanja: greške i prekršaje, pri čemu prva kategorija predstavlja rezultat problema u kognitivnom procesiranju, dok su prekršaji određeni kao namerna kršenja pravila. Upitnik UPS u manjoj meri obuhvata greške, ali aspekt Kršenje propisa očigledno odgovara onome što je u DBQ određeno kao prekršaji. Generalno, može se reći da novokonstruisani upitnik UPS obuhvata relativno širok spektar relevantnih indikatora ponašanja pri vožnji i može biti koristan instrument za procenu potencijalno rizičnog ponašanja vozača.

Rezultati ovog istraživanja podržavaju gledište da situacije sa kojima se susreće osoba prilikom vožnje provociraju ponašanja koja su u skladu s bazičnim tendencijama sadržanim u stabilnim karakteristikama ličnosti. Analiza strukture relacija osobina ličnosti i različitih vidova ponašanja prilikom vožnje otkrila je postojanje dva obrasca takve povezanosti. Prvi opisuje vrlo direktno odražavanje bazične strukture ličnosti u ponašanju prilikom vožnje i ukazuje na to da impulsivne i agresivne osobe ispoljavaju ove osobine i dok voze. Visoki skorovi na dimenziji Agresivnost-hostilnost, udruženi sa visokim skorovima na Impulsivnosti, u situaciji upravljanja automobilom oblikuju nervozni, „bezobrazni“, impulsivni stil vožnje u kome dominira negativni afekat, nestrpljenje i ignorisanje tuđih potreba. Prateći elementi ovakvog ponašanja pri vožnji su: sklonost rizicima, takmičarsko ponašanje, udovoljavanje trenutnim impulsima. Ovi rezultati su u skladu sa rezultatima ranijih studija koje su identifikovale dimenziju Traženje senzacija kao značajan prediktor rizične vožnje (Oltedal \& Rundmo, 2006; Dahlen \& White, 2006; Iversen \& Rundmo, 2002), s tom razlikom da je u ovom istraživanju pokazan značaj isključivo Impulsivnosti kao subdimenzije Impulsivnog traženja senzacija. Ovaj rezultat, među- 
tim, može biti i posledica visoke korelacije između dve subdimenzije Impulsivnog traženja senzacija, čemu u prilog ide i činjenica da Traženje senzacija ostvaruje značajno kanoničko opterećenje kada je u pitanju prvi kanonički faktor iz prostora osobina ličnosti (Prilog 3), iako koeficijent u matrici strukture nije značajan. Interesantno je da Kršenje propisa nema udela u opisanom načinu vožnje, što može značiti da je sklonost prekršajima relativno rasprostranjena $u$ našoj sredini i nije rezervisana samo za kategoriju agresivnoimpulsivnih vozača. Međutim, s obzirom na to da Kršenje propisa ima značajno kanoničko opterećenje na prvom kanoničkom faktoru levog seta, moguće je da se i ovde radi o supresorskom dejstvu ostalih faktora koji su s njim u korelaciji.

Drugi obrazac povezanosti osobina ličnosti i ponašanja u vožnji povezuje stepen tolerancije, miroljubivosti i potrebe za aktivnošću sa odgovornošću i uživanjem u vožnji. Sklonost prekršajima donekle dovodi u pitanje objašnjenje da nizak skor na kanoničkom faktoru iz upitnika UPS opisuje odgovoran odnos prema vožnji. Moguće je da je takvo kršenje propisa više efekat potrebe da se uživa u vožnji (npr. brzina), ili samouverenosti kada su u pitanju veštine vožnje, zbog čega bi osoba sa ovakvim stilom vožnje mogla smatrati da je u stanju da sama proceni šta sme da radi na putu a da pri tome ne ugrožava sebe i druge. Na osnovu konteksta ostalih karakteristika u kojima se pojavljuje ova sklonost prekršajima, može se pretpostaviti da ovde nisu u pitanju prekršaji koji direktno mogu ugroziti nečiju bezbednost u saobraćaju, i da osobe sa visokim skorovima na ovoj kanoničkoj dimenziji u osnovi voze bezbedno. Međutim, ne mora biti tako. Ovaj rezultat bi se mogao dovesti u vezu sa nalazima koji pokazuju da visoke ili precenjene vozačke veštine mogu biti rizične ukoliko nisu balansirane veštinama usmerenim na obezbeđenje sigurnosti (Sümer, Özkan \& Lajunen, 2006), kao i, posredno, sa onim rezultatima koji upućuju na povezanost između emocionalne stabilnosti i agresivne vožnje (Dahlen \& White, 2006).

Ako se nizak skor na kanoničkim faktorima prvog para tretira kao visoko rizičan oblik vožnje, a na faktorima drugog para kao blago rizičan, onda se čini da osnovnu razliku čini pozicija dimenzije Agresivnost-hostilnost. Ona, izgleda, oblikuje osnovni afekat koji prati vozačko ponašanje, i tako posredno dovodi do više ili manje napete i rizične vožnje. Značaj ove osobine za ponašanje pri vožnji je takođe pokazan $u$ dosadašnjim istraživanjima (Deffenbacher et al., 2000; Deffenbacher et al., 2003).

U istraživanju nije pokazan veći značaj dimenzije Neuroticizam-anksioznost za vozačko ponašanje. Ova dimenzija, doduše, ostvaruje značajno kanoničko opterećenje kada je u pitanju prvi kanonički par, što znači da ima izvesnu, ali 
ipak sporednu, ulogu u oblikovanju visoko rizičnog stila vožnje. Socijabilnost uopšte nije pokazala značaj u ovom kontekstu, dok se uloga Aktiviteta, konkretnije Radnog aktiviteta, može shvatiti kao deo obrasca koji obezbeđuje relativno odgovoran pristup vožnji. Aktivitet i Socijabilnost se mogu posmatrati kao aspekti ekstraverzije, dimenzije čiji je značaj za vožnju pokazan u nekim istraživanjima (Verwey \& Zaidel, 2000). Međutim, ekstraverzija se najviše dovodi u vezu s vigilnošću, te je verovatno važnija za aspekte vozačkog ponašanja koji nisu obuhvaćeni ovim istraživanjem, kao što su koncentracija ili zamaranje.

S obzirom na to da su saobraćajne nezgode retki događaji, veoma je teško ustanoviti prediktivnu moć osobina ličnosti kada su u pitanju takvi incidenti. Međutim, relacije osobina ličnosti sa različitim oblicima ponašanja u vožnji koji se mogu okarakterisati kao manje ili više rizični, indirektno mogu dati neke podatke korisne za prevenciju saobraćajnih nezgoda. Potencijalna primenljivost ovih rezultata ogleda se u mogućnosti kreiranja programa prevencije nezgoda koji bi bili prilagođeni karakteristikama ličnosti vozača. I u procesu obuke vozača, pogotovo ukoliko se ona ne shvati isključivo kao usvajanje veština vožnje i učenje saobraćajnih propisa, ovakva saznanja mogla bi imati svoju primenu. Pored usmerenosti na poboljšavanje performansi prevoznih sredstava i na konstrukciju takozvanih Smart sistema u cilju olakšavanja vožnje, za povećanje bezbednosti u saobraćaju izuzetno je važno edukovanje i razvijanje odgovornog ponašanja vozača u saobraćaju.

\section{Reference}

Dahlen, E. R., \& White, R. P. (2006). The Big Five factors, sensation seeking, and driving anger in the prediction of unsafe driving. Personality and Individual Differences, 41, 903-915.

Deffenbacher, J. L., Filetti, L. B., Richards, T. L., Lynch, R. S. Oetting, E. R. (2003). Characteristics of Two Groups of Angry Drivers. Journal of Counseling Psychology, 50, 123-132.

Deffenbacher, J. L., Huff, M. E., Lynch, R. S., Oetting, E. R., \& Salvatore, N. F. (2000). Characteristics and Treatment of High-Anger Drivers. Journal of Counseling Psychology, 47, 5-17.

Deffenbacher, J. L., Lynch, R. S., Oetting, E. R., \& Swaim, R. C. (2002). The Driving Anger Expression Inventory: A measure of how people express their anger on the road. Behaviour Research and Therapy, 40, 717-737. 
Deffenbacher, J. L., Oetting, E. R., \& Lynch, R. S. (1994). Development of a driving anger scale. Psychological Reports, 74, 83-91.

Donovan, D. M., \& Marlatt, G. A. (1982). Personality Subtypes Among Driving-While-Intoxicated Offenders: Relationship to Drinking Behavior and Driving Risk. Journal of Consulting and Clinical Psychology, 50, 241-249.

Iversen, H., \& Rundmo, T. (2002). Personality, risky driving and accident involvement among Norwegian drivers. Personality and Individual Differences, 33, 1251-1263.

Lajunen, T. (2001). Personality and accident liability: are extraversion, neuroticism and psychoticism related to traffic and occupational fatalities? Personality and Individual Differences, 31,1365-1373.

Matthews, G., \& Desmond, P. A. (1998). Personality and multiple dimensions of task-induced fatigue: a study of simulated driving. Personality and Individual Differences, 25, 443-458.

Millar, M. (2007). The influence of public self-consciousness and anger on aggressive driving. Personality and Individual Differences, 43, 2116-2126.

Nolan Y., Johnson, J. A., \& Pincus, A. L. (1994). Personality and Drunk Driving: Identification of DUI Types Using the Hogan Personality Inventory. Psychological Assessment, 6, 33-40.

Oltedal, S. \& Rundmo, T. (2006). The effects of personality and gender on risky driving behaviour and accident involment. Safety science, 44, 621628.

Özkan, T. \& Lajunen, T. (2005). Multidimensional Traffic Locus of Control Scale (T-LOC): factor structure and relationship to risky driving. Personality and Individual Differences, 38, 533-545.

Özkan, T., Lajunen, T., \& Summala, H. (2006). Driver Behaviour Questionnaire: A follow-up study. Accident Analysis and Prevention 38 (2006) 386-395

Srpski komitet za bezbednost saobraćaja (2009). Činjenice. Retrieved Februar, 2009 from: http://www.kbs.org.yu/kbs/pages/cinjenice.php

Sümer, N., Özkan, T., \& Lajunen, T. (2006). Asymmetric relationship between driving and safety skills. Accident Analysis and Prevention, 38, 703-711.

Thiffault, P., \& Bergeron, J. (2003). Fatigue and individual differences in monotonous simulated driving. Personality and Individual Differences, 34, 159-176. 
Tillman, W. A. \& Hobbs, G. E. (1949). The acident prone atomobile driver. American Journal of Psychiatry, 106, 321-331.

Verwey, W. B., Zaidel, D. M. (2000). Predicting drowsiness accidents from personal attributes, eye blinks and ongoing driving behaviour. Personality and Individual Diferences, 28, 123-142.

Vukadinović, V. (1979). Osnovi saobraćajne psihologije. Beograd: Autosaobraćajni obrazovni centar

Vukobrat, S. (2008). Osobine ličnosti i ponašanje vozača u saobraćaju. Diplomski rad. Filozofski fakultet, Univerzitet u Novom Sadu, Novi Sad

Zuckerman, M. (2002). Zuckerman-Kuhlman Personality Questionnaire (ZKPQ): An alternative five factorial model. In B. DeRaad and M. Perusini (Eds.), Big Five Assessment (pp. 377 - 396). Seattle: Hogrefe and Huber Publishers.

Zuckerman, M. \& Kuhlman, D. M. (2000). Personality and Risk-Taking: Common Biosocial factors. Journal of Personality 68, 999-1029.

Zuckerman, M., Joireman, J., Kraft, M., \& Kuhlman, M. D. (1999). Where do motivational and emotional traits fit within three models of personality? Personality and Individual Differences, 26, 487-504. 


\section{Prilozi}

Prilog 1. Karakteristični koreni i procenat objašnjene varijanse glavnih komponenti Upitnika o ponašanju vozača u saobraćaju

\begin{tabular}{ccccc}
\hline \multirow{2}{*}{ Komponenta } & \multicolumn{3}{c}{ Inicijalno rešenje } & Rotirano rešenje \\
\cline { 2 - 5 } & $\begin{array}{c}\text { Karakteristični } \\
\text { koren }\end{array}$ & $\begin{array}{c}\text { Procenat } \\
\text { varijanse }\end{array}$ & $\begin{array}{c}\text { Kumulativni } \\
\text { procenat }\end{array}$ & $\begin{array}{c}\text { Karakteristični } \\
\text { koren }\end{array}$ \\
\hline 1 & 9.674 & 18.968 & 18.968 & 7.393 \\
2 & 4.233 & 8.300 & 27.268 & 7.097 \\
3 & 2.675 & 5.246 & 32.513 & 4.572 \\
4 & 2.243 & 4.398 & 36.912 & 5.991 \\
\hline
\end{tabular}

Prilog 2. Izvodi iz matrica sklopa Promax glavnih komponenti ekstrahovanih iz upitnika UPS Prva promax glavna komponenta: izvod iz matrice sklopa

\begin{tabular}{lll}
\hline UPS22 & Izazvao/la sam saobraćajni udes. & .661 \\
UPS33 & $\begin{array}{l}\text { Više puta sam kažnjavan/a zbog za prekršaje koje ne podrazu- } \\
\text { mevaju nepropisno parkiranje. }\end{array}$ & .636 \\
UPS9 & Kažnjen/a sam više puta zbog nepropisnog parkiranja. & .608 \\
UPS17 & Više puta sam kažnjen/a zbog prebrze vožnje. & .598 \\
UPS45 & Krivično sam gonjen/a zbog prekršaja koji sam počinio/la. & .556 \\
UPS6 & Često dovodim sebe u rizične situacije u saobraćaju. & .547 \\
UPS28 & Vozim i ako popijem više nego što je dozvoljeno. & .537 \\
UPS13 & Pretičem druge automobile i kada uslovi za to nisu najpovoljniji. & .406 \\
\hline
\end{tabular}

Druga promax glavna komponenta: izvod iz matrice sklopa

\begin{tabular}{llc}
\hline UPS40 & Ne volim brzu vožnju. & -.804 \\
UPS34 & Često mi se desi da prodem kroz crveno. & .589 \\
UPS48 & Smatram da vozim staloženo i odgovorno. & -.588 \\
UPS49 & Vozim oštro. & .581 \\
UPS35 & Uglavnom poštujem saobraćajna pravila. & -.532 \\
UPS36 & Parkiram najbliže mestu na koje idem, pa iako "zagradim" ne- & .519 \\
& kog. & .438 \\
UPS39 & Jedem u kolima dok vozim. & .377 \\
UPS7 & Vozim brže od vecine ljudi. & .348 \\
UPS27 & Razgovaram mobilnim telefonom dok vozim. & \\
\hline
\end{tabular}


Treća promax glavna komponenta: izvod iz matrice sklopa

\begin{tabular}{lll}
\hline UPS25 & Verujem da je mojim saputnicima prijatno kada ih vozim. & .720 \\
UPS8 & Sebe smatram spretnom osobom kada je u pitanju vožnja. & .706 \\
UPS5 & Smatram da vozim bezbedno. & .701 \\
UPS1 & Smatram da vozim sigurno. & .678 \\
UPS42 & Volim da vozim. & .655 \\
UPS38 & Više volim da ja vozim nego da me drugi voze. & .613 \\
UPS37 & Često proveram ispravnost svog vozila. & .530 \\
UPS2 & Poštujem prvenstvo prolaza na raskrsnicama. & .451 \\
UPS43 & Nisam nervozan/a dok vozim. & .386 \\
UPS44 & Volim velika i brza kola. & .371 \\
\hline
\end{tabular}

Četvrta promax glavna komponenta: izvod iz matrice sklopa

\begin{tabular}{llc}
\hline UPS23 & Nerviraju me ljudi koji "kilave" u saobraćaju. & .803 \\
UPS15 & Psujem dok vozim. & .680 \\
UPS19 & Nerviraju me biciklisti koji voze van biciklističke staze. & .648 \\
UPS14 & Nerviraju me penzioneri u sabraćaju. & .596 \\
UPS20 & $\begin{array}{l}\text { Kada vozim van grada. imam potrebu da preteknem vozilo ispred } \\
\text { sebe. čak i ako se ono ne kreće sporo. }\end{array}$ & .470 \\
UPS4 & $\begin{array}{l}\text { Trubim kada neko na semaforu ne krene čim se upali zeleno svet- } \\
\text { UPS41 }\end{array}$ & $\begin{array}{l}\text { lo. } \\
\text { Nerviraju me žene u saobraćaju. }\end{array}$ \\
\hline
\end{tabular}

Matrica interkorelacija promax glavnih komponenti

\begin{tabular}{lcccc}
\hline & $\begin{array}{c}\text { Kršenje pro- } \\
\text { pisa }\end{array}$ & $\begin{array}{c}\text { Impulsivna } \\
\text { vožnja }\end{array}$ & $\begin{array}{c}\text { Bezbedna } \\
\text { vožnja }\end{array}$ & $\begin{array}{c}\text { Razdražljivost } \\
\text { pri vožnji }\end{array}$ \\
\hline Kršenje propisa & 1.000 & .431 & -.143 & .425 \\
Impulsivna vožnja & .431 & 1.000 & -.061 & .433 \\
Bezbedna vožnja & -.143 & -.061 & 1.000 & -.055 \\
Razdražljivost pri & .425 & .433 & -.055 & 1.000 \\
vožnji & & & \\
\hline
\end{tabular}


Prilog 3. Matrice kanoničkih opterećenja

Kanonička opterećenja faktora iz prostora skale UPS

\begin{tabular}{lcc}
\hline & Prvi kanonički faktor & Drugi kanonički faktor \\
\hline Kršenje propisa & $-\mathbf{0 . 4 5 2}$ & $\mathbf{0 . 3 8 6}$ \\
Impulsivna vožnja & $-\mathbf{0 . 7 3 6}$ & -0.141 \\
Bezbedna vožnja & -0.080 & $\mathbf{- 0 . 7 5 2}$ \\
Razdražljivost pri vožnji & $\mathbf{- 0 . 9 1 4}$ & 0.209 \\
\hline
\end{tabular}

Kanonička opterećenja faktora iz prostora skale ZKPQ

\begin{tabular}{lcc}
\hline & Prvi kanonički faktor & Drugi kanonički faktor \\
\hline Traženje senzacija & $\mathbf{- 0 . 5 6 1}$ & $\mathbf{- 0 . 3 5 8}$ \\
Impulsivnost & $\mathbf{- 0 . 6 8 0}$ & $\mathbf{- 0 . 4 2 1}$ \\
Neuroticizam-anksioznost & $-\mathbf{0 . 3 1 8}$ & 0.289 \\
Agresivnost-hostilnost & $-\mathbf{0 . 8 5 4}$ & $\mathbf{0 . 4 8 1}$ \\
Generalni aktivitet & 0.261 & $\mathbf{- 0 . 3 4 1}$ \\
Radni aktivitet & -0.175 & $\mathbf{- 0 . 4 5 9}$ \\
Sklonost druženju i zabavama & $\mathbf{- 0 . 3 5 3}$ & $\mathbf{- 0 . 4 0 0}$ \\
Tolerancija na izolaciju & 0.154 & 0.186 \\
\hline
\end{tabular}




\section{ABSTRACT}

\section{PERSONALITY TRAITS AND DRIVING BEHAVIOR}

Sonja Vukobrat and Dušanka Mitrović

The aim of this study was to explore the structure of the relations between personality traits and driving behavior. The study comprised 180 subject with driving licenses, of both sexes, age 18 to 69. The driving behavior was assessed by Driving behavior questionnaire, and personality traits were measured by Zuckerman-Kuhlman Personality Qestionnaire. The Principal component analysis of the Driving behavior questionnaire yielded four components: Rules violation, Impulsive driving, Safe driving and Driver irritability.

The results reveal two patterns of relations between the personality traits and driving behavior. The first one points to the relations of Aggression-hostility and Impulsiveness to irritable and impulsive driving behavior, and suggests that aggressive agitation during driving, as well as certain kinds of risky driving, reflect stable personality traits. The second pattern points to the relation of the non-aggressiveness and activity to responsible driving and positive affect while driving. This pattern suggests that self-confidence concerning driving skills could lead to tendency of violation of rules Overall results point out to the particular significance of Aggression-hostility and Impulsiveness in this context, and could be applied in the area of accident prevention. The findings are mainly consistent with the results of previous research in the field.

Ključne reči: personality traits, Alternative five-factor model of personality, driving behavior 